\title{
Intra-Executive Competition between President and Prime Minister: Patterns of Institutional Conflict and Cooperation under Semi-Presidentialism
}

\author{
Oleh Protsyk \\ European Centre for Minority Issues
}

\begin{abstract}
The article examines the dynamics of political competition over the control of the executive that shapes the coexistence of popularly elected presidents and prime ministers in semi-presidential regimes. It explores how variation in the political status of cabinet and the character of the party system, as well as differences in presidential and parliamentary powers over the cabinet, affects both the type and intensity of intra-executive conflict in democratic and semi-democratic environments. It demonstrates that presidents' and prime ministers' strategies in intra-executive relations in both types of political environment are systematically affected by the nature and extent of cabinet's political support in parliament, as well as by the degree of presidential control over cabinet.
\end{abstract}

The post-communist transition led to the proliferation of semi-presidential regimes in East Central Europe and the Former Soviet Union. The coexistence of popularly elected presidents and prime ministers, which is a distinct feature of a semi-presidential constitutional framework, and which is often labeled as 'intra-executive' coexistence, has proven to be prone to conflict in most of these regimes. Among the factors leading to conflict, scholars often cite personality, ideological differences magnified by certain party system configurations, newness of institutional designs and constitutional ambiguities (Baylis, 1996; Elgie, 1999a; Taras, 1997).Very few attempts, however, have been made to arrive at some comparative framework for analyzing intra-executive conflict.

This article examines the systematic effects that variations in presidential and parliamentary powers over cabinet, in political composition of parliament and in the political status of cabinet have on the probability of intra-executive conflict in semi-presidential regimes. Intra-executive conflict, which is defined as political confrontation between president and prime minister over the control of the executive branch of government, is first put into the framework of institutional relationships among the president, parliament and cabinet. I argue that conceptualizing this relationship in terms of a multiple principal-agent model enhances our understanding of how semi-presidentialism works.

Secondly, I discuss how the political status of cabinet, which is determined by the character of parliamentary composition and the level of party system development, affects the set of incentives that prime ministers face in a semi- 
presidential institutional setting. Thirdly, the instances of intense intra-executive competition and peaceful intra-executive coexistence across the postcommunist region are analyzed according to the framework proposed in the first two sections of the article. Fourthly, I specify a statistical model that allows some preliminary tests of hypotheses about the likelihood of intra-executive conflict under different institutional and political settings. The last section of the article provides a number of conclusions.

There is a substantial body of recent literature devoted to the concept 'semi-presidential government' (Bahro et al., 1998; Elgie, 1998; Pasquino, 1997; Roper, 2002; Siaroff, 2003). The classical Duverger definition of semipresidentialism (Duverger, 1980) is often criticized by these authors, among other things, for its imprecision and lack of conceptual clarity. ${ }^{1}$ A more nuanced interpretation of the second criterion in Duverger's definition led Shugart and Carey (1992) to propose a classification of what can be called sub-types of semi-presidentialism. This article utilizes their concepts of presidentparliamentary and premier-presidential regimes in the discussion of variation in constitutional design of semi-presidential systems.

A president-parliamentary framework, which provides the popularly elected president with the constitutional powers to nominate (or appoint) and to dismiss cabinet, has been in place for most of the post-communist decade and a half in Armenia, Russia and Ukraine. ${ }^{2}$ Because the interest of this research project is in analyzing the effects that a semi-presidential constitutional design has on the motivation of key institutional actors in a democratic setting, only president-parliamentary systems that operate in a fully or partly democratic environment were included in the analysis. ${ }^{3}$ A premier-presidential institutional framework, which empowers the popularly elected president to nominate a prime minister for parliament's confirmation but does not provide him/her with the power to dismiss the prime minister or individual ministers, has been in place for most of the post-communist period in Bulgaria, Lithuania, Moldova, Poland, Romania and Russia (1991-3). ${ }^{4}$ The data on cabinets formed in these two groups of countries constitutes the empirical basis of this research. There were 67 cases of coexistence of popularly elected presidents with different cabinets in these countries during the 1991-2002 period. Whenever I use the term 'semi-presidential' in the text I make generalizations about, or refer to, the features of semi-presidential regimes found both in president-parliamentary and premier-presidential types of semi-presidential systems.

\section{Intra-Executive Relations in Semi-Presidential Constitutional Settings}

Interactions between the presidency, the cabinet and the legislature occupy the center of the political scene in semi-presidential regimes. The numerous ways 
in which the political actors who inhabit these institutions relate to each other can result in confusion about the lines of accountability and responsibility, the chains of command and the patterns of hierarchical control. This confusion is usually attributed to the ambiguities of semi-presidential constitutions. Several earlier attempts to unpack this complicated set of relationships between the above-mentioned institutional actors take as their point of departure an analysis of specific constellations of political resources available for each of the actors (Baylis, 1996; Taras, 1997). A problematic aspect of these analyses is the lack of explicit attention to the relationships of hierarchy and mechanisms of control imposed by specific institutional contexts. Political actors are perceived as playing in a non-hierarchical political market with each actor being endowed with a specific set of resources easily employed in the intra-branch competition.

Structuring post-communist countries' experiences of intra-executive coexistence along theoretical lines requires the explicit recognition of the hierarchical nature of government organization and the distinct patterns of superiority and subordination produced by this hierarchy. The positions of a prime minister and cabinet in a semi-presidential regime can be conceptualized as an agent facing two principals. ${ }^{5}$ Both the president and the parliament, which jointly appoint the cabinet and have various monitoring and sanctioning powers, are the principals of the cabinet. This agency relationship is specified in the semipresidential constitution which makes both the president and the legislature participate in the selection of a prime minister and which stipulates the lines of the prime minister's responsibility to each of the principals.

Prime ministers in semi-presidential regimes face the principals - the president and the legislature - who may be rivals trying to ensure the cabinet's compliance with their distinct objectives. Differing electoral bases and competing political legitimacies are inbuilt characteristics of semi-presidential constitutional frameworks that lay the grounds for potential conflict between the president and parliament. Constitutional provisions regulate how the principals can sanction the cabinet. Constitutions also specify which of the principals has control of the ultimate sanction against the cabinet, which is cabinet dismissal. Principals who formally have more influence over cabinet dismissal are also likely to be more successful in securing the agent's compliance and cooperation. Thus, knowing the exact terms of the selection procedure should help to identify more likely patterns of cooperation across principal-agent lines and the types of major conflicts that a specific semi-presidential regime is likely to develop.

There are two types of conflicts that are theoretically interesting and empirically recurrent in the cases examined in this article: (1) intra-executive conflict, which is characterized by intense confrontation between a president and a prime minister who is supported by parliament; and (2) conflict between a united executive and parliament that takes place when the president and prime minister form an alliance vis-à-vis the legislature. Both types of conflict are the 
products of the same executive-legislative institutional divide between the president and legislature. They provide, however, two alternative channels along which political competition between the executive and legislative branches can be structured.

The multiple principal-agent model leads us to expect that if the parliament exclusively controls the power to dismiss cabinet, conflict between a united executive and parliament is less likely. In this type of political regime, the political system is unlikely to experience situations where the president will be able to secure the loyalty of the prime minister at the expense of parliament. Such asymmetry over control of dismissal powers provides strong incentives for a prime minister to cooperate with parliament and no incentives to cooperate with the president. Wherever the president and parliament have symmetrical powers of cabinet dismissal, knowing the constitutional distribution of dismissal powers does not provide the analyst with clear-cut predictive power. Neither intra-executive nor executive-legislative types of conflict can be ruled out because such a constitutional framework provides the prime minister with mixed incentives. The agent's decisions to ally with either of the principals under this institutional framework will be, to a larger extent, a product of nonconstitutional factors and the political circumstances that cabinets find themselves in. ${ }^{6}$

In terms of our specific interest in how the variation in constitutional powers affects the likelihood of intra-executive conflict, one main hypothesis that will be explored in the following sections of the article is the expectation of a relationship between the strength of presidential dismissal powers and the level of intra-executive conflict:

Hypothesis 1: Cabinet Dismissal Power and Conflict.

Intra-executive conflict is more likely in premier-presidential than in presidentparliamentary regimes.

Emphasizing the constitutionally established patterns of superiority and subordination among the principals and their agent provides a stronger theoretical footing for analyzing intra-executive relationships under semi-presidentialism. At the same time, constitutional norms are only one of the main factors that systematically affect the prime minister's motivation in dealing with principals.

\section{Parliamentary Composition, Cabinet Type and Prime Minister's Stand vis-à-vis the President}

The political composition of parliament is another key variable that helps to explain the prime minister's stand vis-à-vis the principals. Parliamentary support is essential for the prime minister to claim authority over the executive branch of government. Intra-executive relations are critically affected by the nature and the level of parliamentary support that the prime minister enjoys. The nature 
of parliamentary support for the cabinet, in turn, is profoundly shaped by the level of party system development. The maturity of the party system varies across countries in the post-communist region. The low level of party system consolidation, high degree of party instability and greater importance of personalistic ties rather than ideological principles characterize, to a large degree, the functioning of the political systems in post-Soviet president-parliamentary regimes.

These traits of party systems in president-parliamentary regimes were reinforced throughout the period analyzed by the regimes' adherence to mixed electoral formula that combined single-member district and proportional representation. At the same time, all premier-presidential regimes discussed in this article, with the exception of Lithuania, favored electoral systems based exclusively on proportional representation. In the context of post-communist transition, singlemember district representation encouraged not-affiliated candidates to run for parliamentary seats and led to the presence of a large number of independent deputies in parliaments, while proportional representation formulas tended to strengthen the role that political parties played in parliament and in the overall political system. Much weaker institutionalization of party systems in presidentparliamentary regimes, which has been partly a product of regime-type choices made at the early stages of democratic transition, is generally accepted in the literature (Birch, 2000; Golosov, 2003; Lowenhardt, 1998; McFaul, 2001; Moser, 2001; Protsyk and Wilson, 2003).

Although party systems vary significantly across a sample of semi-presidential regimes, political parties in all political systems attempt to build linkages to voters, try to develop mechanisms for representation and aspire to articulate a more or less coherent ideological profile (Kitschelt, 1995; Kitschelt et al., 1999; Lewis, 2001). The ideological orientation of a governing coalition in parliament is the most immediate factor that shapes intra-executive coexistence. It is reasonable to expect that shared ideological orientation of a governing coalition and the president should diminish (but not eradicate) the incentives for intraexecutive competition and, subsequently, for intra-executive conflict:

Hypothesis 2: Partisanship and Conflict.

Shared ideological orientation of the president and cabinet decreases the likelihood of intra-executive conflict.

The extent and character of parliamentary support that prime ministers enjoy is translated in the types of cabinets they form. A prime minister's position visà-vis the president is the strongest when she/he is the leader of the majority coalition in parliament. When this coalition is of a different political orientation than the president, intra-executive peace can become very problematic. Although the most well-known situations when the presidents and prime ministers of a different political orientation coexisted - the so-called periods of cohabitation in the French Fifth Republic - did not lead to intra-executive 
confrontation, the existing literature warns us that the problems of cohabitation should not be underestimated. ${ }^{7}$

The French experience, however, might not be unique if one takes into account the deterrent effect that the existence of an ideologically opposed parliamentary majority has on presidents aspiring to have a greater control over the executive. Rather than attributing the peacefulness of coexistence to the idiosyncratic characteristics of the French political process, one has to take into account the presidential calculation of the political costs involved in challenging a politically strong prime minister. The presence of an ideologically coherent parliamentary majority that opposes the president may raise these costs to a prohibitive level and may serve as an effective deterrent to presidential ambitions to renegotiate the existing distribution of executive powers. Besides changing the expectations about the prospects of coexistence of the presidents with the prime ministers backed by an ideologically opposed majority in parliament, this interpretation of French cohabitation invites further questions regarding the effects that the variation in cabinet type has on the motivations of presidents and prime ministers and their willingness to engage in intraexecutive competition.

Minority party cabinets and cabinets without party affiliation (technocratic cabinets) were a frequent phenomenon in the countries under investigation. ${ }^{8}$ They were largely the products of parliamentary fragmentation or weaknesses in the ideological and organizational structuration of the party system. There is little theoretical guidance in existing literature on how the minority or technocratic status of cabinets affects the character of relationships between presidents and prime ministers.

This article's other main hypothesis is that the variation in political strength of cabinet has a systematic effect on the likelihood of intra-executive conflict:

Hypothesis 3: Cabinet Type and Conflict.

Intra-executive conflict is more likely when a president co-exists with minority rather than majority or technocratic cabinets.

At the core of intra-executive conflict is the president's willingness to challenge the prime minister's control of the executive, and the prime minister's unwillingness to acquiesce to presidential preferences. Minority cabinets are more likely to experience intra-executive conflict because their perceived political weakness provides incentives for the president to pursue strategies for achieving a greater involvement in executive matters. While the majority status of cabinet imposes constraints on presidential ambitions, the minority status of cabinet weakens presidential reservations about attempting to secure a greater say in executive matters. At the same time, an increase in presidential eagerness to demand a change in the existing executive status quo is not matched by the minority prime minister's willingness to acquiesce to presidential demands. The 
level of the prime minister's compliance with presidential demands is likely to be a function of the nature of political support that the prime minister relies on in parliament. Minority cabinets are largely the products of ideologically structured but fragmented party systems. The stronger the ideological rather than clientelistic structuration of party-based parliamentary composition, the less likely the prime minister is to acquiesce to presidential bids for a greater control of the executive.

A high level of party fragmentation, combined with the predominantly clientelistic structuring of the party system, led to the persistence in some postcommunist countries of yet another cabinet type, the technocratic cabinet. Prime ministers who are in charge of technocratic cabinets find themselves in a different strategic environment from their counterparts who lead party-based cabinets. The lack of steady and unconditional parliamentary support, as well as a generally greater presidential contribution to the appointment of technocratic prime ministers to the office in the first place, makes them especially dependent on the president. Their political vulnerabilities also make them more willing to accept presidential leadership in executive matters.

To see whether the differences in cabinet type and cabinet partisanship, as well as variation in cabinet dismissal powers, affect the likelihood of intraexecutive competition and whether these differences correlate with prime ministers taking a more confrontational or more accommodationist stand

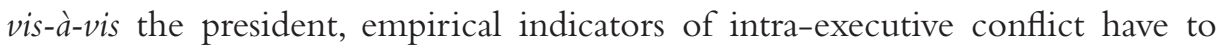
be developed.

\section{Measuring Intra-Executive Conflict in Post-Communist Semi-Presidential Regimes}

Intra-executive conflict was previously described as political competition between the president and prime minister over the control of political resources available to the executive branch of government. The coexistence of the president and the cabinet is characterized as an instance of intra-executive conflict when either the president or prime minister contests the status quo interpretations of constitutional and statutory norms that regulate power relations inside the executive, or contests the norms themselves. The manifestations of intra-executive competition are ubiquitous. For example, conflicts arise over policy design in specific issue areas, over the right to issue executive orders and regulations, over reporting and execution routines inside the executive and over the practices of presidential participation in cabinet meetings. The presidents and prime ministers also contest individual appointments to cabinet or other government positions made by the other side or try to dispute decisions about the dismissals of government officials. Although numerous laws and other statutory acts often try to provide a detailed description of powers that belong to the president and prime minister, no legal document can fully regulate 
all the aspects of power relations inside the executive. The rights to exercise discretionary power in situations that are not explicitly regulated by formal procedures are often described as residual rights (Frye, 1997). Intra-executive relations are often conflict prone when there is no tacit agreement between the president and prime minister about who controls residual rights.

Trying to change the formal distribution of powers is the most radical alternative that the rival institutional actors can opt for to redress the existing power balance inside the executive. As the next two sections of the article indicate, in the cases presented both presidents and prime ministers resorted to the tactic of challenging the legitimacy or rationality of the existing constitutional framework. The frequently used strategy was to appeal to the parliament and/or directly to the voters, advocating the change of the basic constitutional norms that regulate the distribution of appointment, executive and legislative powers among the different state institutions.

Scholarly accounts of intra-executive relations were used to identify the cases where a high level of political contestation characterized the coexistence of the president and the cabinet. A comparative cross-country analysis of intraexecutive relations was facilitated by the fact that the East European Constitutional Review (EECR) publishes quarterly country reports that include detailed accounts of executive-legislative relations in the post-communist region. These country reports were studied in order to establish whether any instances of intra-executive confrontation were reported during the analyzed period. ${ }^{9}$ A simple dichotomous classification of low/high level of conflict was employed. If no confrontation between the president and prime minister or only isolated instances of tensions, which arose from a specific policy or appointment issue, were reported, intra-executive relations were classified as a case of lowconflict intra-executive coexistence. When tensions between the president and prime minister were persistent and involved the general principles of subordination and accountability in the executive, or when policies were contested across a large spectrum of issue areas, the level of conflict was considered to be high. ${ }^{10}$

The case of the second cabinet led by Prime Minister Paksas in 2000-1 in Lithuania could serve as an example to illustrate how coding decisions were made in cases that are on the borderline of the high-conflict threshold. The EECR reported serious public disagreements between Paksas and President Adamkus about agricultural subsidies in the spring of 2001. This fact alone would not qualify their coexistence as an example of a high level of conflict. The EECR reports, however, indicate that this disagreement was followed by President Adamkus's strong criticism of cabinet actions across various policy areas, and presidential withdrawal of support for the cabinet whose formation which took place just a few months earlier was perceived as strongly favored by the president (EECR, 2001). 
The Appendix lists all cabinets formed under a semi-presidential constitutional framework in the post-communist countries included in this research and indicates the level of intra-executive conflict during the incumbency of each cabinet. Change of a prime minister, change in the party composition of a cabinet or a simultaneous change of more than 50 per cent of cabinet ministers were taken as indication of cabinet change. When a newly elected or re-elected president had to coexist with the cabinet formed prior to the presidential election, such situations were also classified as new cases of intraexecutive coexistence.

Table 1 summarizes the data from the Appendix. The cases are classified according to the regime type and level of intra-executive competition. Only the cases of high conflict are denoted by the name of the prime minister during whose tenure intra-executive competition took place. The table shows that instances of intra-executive conflict were recorded in all semi-presidential regimes. Overall, intra-executive confrontation was a more frequent phenomenon among premier-presidential regimes. In both types of semi-presidential regimes the instances of intra-executive conflict were not equally distributed across the countries. In the group of premier-presidential regimes, intra-executive relations were the most conflictual in Poland. Armenia and Ukraine share the same record for president-parliamentary regimes. The smallest number of instances of intra-executive confrontation was recorded in Romania and Russia, premierpresidential and president-parliamentary regimes respectively.

In Poland, a high level of intra-executive conflict characterized most of Walesa's incumbency as president. Analysts attribute the persistence of intra-executive competition in Poland to the unwillingness of President Walesa to accept the prime minister's leadership in executive matters. It is important to note that in the quest for control of the executive, the Polish president challenged not only the relatively weak minority coalition government led by Prime Minister Olszewski but also Pawlak and Oleksy's cabinets which relied on the support of a stable coalition majority in parliament (Jasciewicz, 1997). The growing consolidation of democratic institutions and the transfer of the presidency from Walesa to Kwasniewski profoundly affected the nature of intra-executive relations but did not eliminate built-in structural incentives for conflict. Veto wars characterized Kwasniewski's coexistence with Buzek cabinets. While the president did not openly contest prime ministerial leadership over the executive, the frequency with which he vetoed laws initiated by the cabinet across a large number of policy areas, especially during 2000, indicates that the president actively and systematically contested cabinet policies.

Both in Armenia and Ukraine, the instances of confrontation between the president and prime minister over the distribution of executive powers took place during the incumbency of both presidents. Presidents Ter-Petrosian and Kocharyan in Armenia and Presidents Kravchuk and Kuchma in Ukraine 
Table 1: Intra-Executive Competition in Semi-Presidential Regimes:

Distribution of Cases, 1991-2002

\begin{tabular}{|c|c|c|c|}
\hline & & \multicolumn{2}{|c|}{ Level of intra-executive conflict } \\
\hline & & \multirow[b]{2}{*}{ Low } & \multirow{3}{*}{$\begin{array}{c}\text { High } \\
\text { ( } N \text { of cases, \% of } \\
\text { cases, and prime } \\
\text { ministers' names) }\end{array}$} \\
\hline & & & \\
\hline & & $\begin{array}{l}\text { ( } N \text { of cases, } \\
\% \text { of cases) }\end{array}$ & \\
\hline \multirow[t]{23}{*}{$\begin{array}{l}\text { Type of semi- } \\
\text { presidential regime }\end{array}$} & $\begin{array}{l}\text { Premier- } \\
\text { presidential }\end{array}$ & $25(64 \%)$ & $14(36 \%)$ \\
\hline & & & Brazauskas 01- (Lithuania) \\
\hline & & & Buzek 97-00 (Poland) \\
\hline & & & Buzek 00-01(Poland) \\
\hline & & & Dimitrov 91-92 (Bulgaria) \\
\hline & & & Gotha/np 02- (Bulgaria) \\
\hline & & & Oleksy 95-96 (Poland) \\
\hline & & & Olszewski 91-92 (Poland) \\
\hline & & & Pawlak 93-95 (Poland) \\
\hline & & & Roman 90-91 (Romania) \\
\hline & & & Sangheli 94-96 (Moldova) \\
\hline & & & Vagnorius 98-99 (Lithuania) \\
\hline & & & Vasile 98-00 (Romania) \\
\hline & & & Videnov 95-97 (Bulgaria) \\
\hline & & & Paksas 00-01 (Lithuania) \\
\hline & $\begin{array}{l}\text { President- } \\
\text { parliamentary }\end{array}$ & $21(75 \%)$ & $7(25 \%)$ \\
\hline & & & Arutyunyan 92-93 (Armenia) \\
\hline & & & Kocharyan 97-98 (Armenia) \\
\hline & & & Kuchma 92-93 (Ukraine) \\
\hline & & & Lazarenko 96-97 (Ukraine) \\
\hline & & & Marchuk 95-96 (Ukraine) \\
\hline & & & Primakov 98-99 (Russia) \\
\hline & & & Sargsyan 99-00 (Armenia) \\
\hline
\end{tabular}

challenged the prime ministers with whom they coexisted throughout the first post-communist decade. The Ukrainian cases are especially intriguing given that two of the three prime ministers involved in intra-executive competition - Marchuk and Lazarenko - were perceived at the moment of their cabinets' formation as closer to the ideal point of the president rather than the parliament. Yet it did not prevent them from withdrawing their support from and opting for open confrontation with the president (Harasymiw, 2002). 
Although they share many similarities, intra-executive relations in presidentparliamentary and premier-presidential regimes developed distinct patterns reflecting different historical legacies, region-specific trajectories of party system development and differences in constitutional provisions regulating the relationships among government branches. The next two sections of the article examine in greater detail some of these patterns.

\section{Intra-Executive Competition in President- Parliamentary Regimes}

Instances of intra-executive competition in Armenia and Ukraine constitute the majority of cases in the lower right corner of Table 1. In Russia, open confrontation between the president and prime minister took place during the tenure of only one cabinet. The finding that intra-executive competition was relatively rare in the case of Russia is consistent with the expectation that intraexecutive competition is less likely in president-parliamentary regimes with constitutional constraints on the parliament's ability to sanction cabinet than in president-parliamentary regimes without such constitutional constraints.

The 1993 Russian constitution, which was designed almost single-handedly by the president, gave him the option of dissolving parliament when it votes no confidence in the cabinet. Although the 1995 Armenian constitution provided the president with the general power to dissolve the parliament, it did not contain any provision that would justify dissolution of parliament by the president in cases where the former carries a vote of no confidence. In the case of Ukraine after 1996, the president is deprived of the power of dissolution in all but very specific circumstances in which parliament is unable to convene for the regular session. The amendments to the old Soviet constitution, which were in place between 1991 and 1995, explicitly prohibited the president from dissolving parliament under any circumstances. The Ukrainian President Kuchma, whose bargaining power in the constitution-making process was much weaker than that of Yeltsin, was also unsuccessful in securing cabinet dismissalrelated dissolution powers in the new constitution adopted in June 1996. ${ }^{11}$ The presidential ability to threaten parliament's survival undoubtedly made cabinet dismissal much costlier for the deputies in the Russian legislature than in the parliaments of the other two countries. Dissolution powers, which are available to the Russian president, cover not only the stage of cabinet dismissal but also the stage of cabinet formation. Under the 1993 Russian constitution the president can dissolve parliament if the process of cabinet formation is stalled. The constitutional right to exercise dissolution powers during cabinet formation helps the president to secure the selection of a prime minister who is close to his/her ideal point, thus further minimizing the extent of potential tensions between them in the future. ${ }^{12}$

The systematic analysis of president-prime minister relations in Russia conveys the image of relatively peaceful intra-executive coexistence. Intra-executive 
politics have been persistently dominated by the presidents who have had the final say in major appointment and policy decisions. Disagreements between the president and prime minister were not perceived by political analysts as highly consequential for the functioning of the executive. When the dismissal of the cabinet was initiated by the president, the reasons cited as grounds for the decision included performance failures and policy mistakes. No allegations of political disloyalty of the prime minister and his cabinet were made on the part of the president in the vast majority of cases. Overall, the level of intraexecutive conflict was low (Huskey, 1999; White, 1999). ${ }^{13}$ In Armenia and Ukraine, on the other hand, the evolution of intra-executive relations was regularly punctuated by instances of intra-executive confrontation. Unlike in Russia, prime ministers in these two countries truly faced the problem of confused or dual loyalty and often chose to ally with parliament at the cost of alienating the presidents. As was illustrated earlier, even those prime ministers who were generally perceived as closer to the president rather than the parliamentary majority at the time of cabinet formation chose this strategy.

\section{Why do Prime Ministers in President-Parliamentary Regimes Defect?}

It might appear puzzling that some prime ministers in president-parliamentary regimes opt for open confrontation with the president. Such confrontation leads, as a rule, to the dismissal of the prime minister by the president. Assuming that staying in office is the first-order preference for the prime minister, it is irrational for the latter to contest openly the president's leadership of the cabinet. It is certainly political suicide for the prime minister in Russia, a president-parliamentary regime with strong presidential control over cabinet. It is also true in Armenia and Ukraine, where the actual symmetry of presidential and parliamentary power over cabinet dismissal would suggest that the prime minister's dominant strategy should be to 'balance' the preferences of the president and parliament and to avoid contesting presidential control over the executive branch of government. Yet, in all three president-parliamentary regimes, prime ministers defected, though at different rates. Table 1 indicates that a high level of intra-executive political conflict characterized the functioning of the following seven cabinets: Arutyunyan 1992-3, Kocharyan 1997-8, Sargsyan 1999-2000 in Armenia; Kuchma 1992-3, Marchuk 1995-6 and Lazarenko 1996-7 in Ukraine; Primakov 1998-9 in Russia.

The explanation for the prime ministers' 'defection' should be sought in the specific structure of the incentives that the president-parliamentary framework produces for prime ministers, and in the prime ministers' subjective calculations of the political strength of the presidents they dare to challenge. One issue that immediately emerges from examining the details of intra-executive competition in all cases considered here is the presidential ambition of the prime minister. Under the president-parliamentary arrangements adopted in Russia, 
Ukraine and Armenia, the presidency is the office that is vested with the highest degree of power and prestige. While in premier-presidential regimes the larger share of executive powers is awarded by the constitution to the prime minister and political practice drifts toward a higher degree of prime ministerial control over the executive branch, president-parliamentary regimes experience both formal and informal consolidation of executive power in the hands of the president. Therefore, the post of president is the most desired one for ambitious politicians.

The office of prime minister, on the other hand, does not have a similar promise of prestige and power for the office seekers. What it does, however, is immediately to promote its holders to a position of national recognition and provide them with some substantial powers over the state apparatus. These are very important assets, especially in political systems that are dominated by personalistic political networks and where both national and local politics are organized around clientelistic rather than ideological appeals. The importance of these assets is further heightened by the fragmentation and instability of the party systems. Prime ministers, because of their control of government resources and name recognition on a national level, have the ability to organize electoral coalitions and party machines for seeking the highest office. In other words, serving as prime minister has the potential to put the politician in the race for the presidency. Five out of seven former prime ministers whose stays in office were characterized by a high level of intra-executive competition had entered or planned to enter the next presidential race to be held in their respective countries: Kocharyan 1997-8 in Armenia; Kuchma 1992-3, Marchuk 1995-6 and Lazarenko 1996-7 in Ukraine; Primakov 1998-9 in Russia. Due to imprisonment, which followed corruption charges, the former Ukrainian prime minister, Lazarenko, was the only one of the five who did not officially enter the presidential race. Prior to his imprisonment he was widely regarded as a potential presidential candidate.

Although the state apparatus and not party politics has thus far generated the main presidential contenders in the regimes under consideration, the growing maturity of political parties and their increasing ability to produce political (and not technocratic) candidates for the premiership may change the dynamics of intra-executive relations in president-parliamentary regimes. To date, the weak institutionalization of the party system has been largely responsible for the fact that politics in president-parliamentary regimes has been dominated by technocratic cabinets. Fragmented and politically unstable parliaments lacked the capacity to produce political prime ministers and party-based cabinets for most of the first post-communist decade. Only cabinets formed after the 1999 parliamentary elections in Armenia can be considered as truly political rather than technocratic (Fuller, 1999). In Russia and Ukraine cabinets continued to be formed on largely technocratic principles during the entire 1991-2002 period, which is in marked contrast to the majority of democratic semi-presidential 
regimes found in post-communist Europe (Morgan-Jones and Schleiter, 2004; Protsyk, 2003).

\section{Intra-Executive Conflict in Premier-Presidential Regimes}

While in president-parliamentary regimes it is prime ministers who challenge presidential leadership over the executive branch of government, the principal executive powers in premier-presidential regimes lie in the hands of cabinets, and it is presidents who challenge prime ministers' authority over the executive. As with president-parliamentarism, the reasons for conflict are structurally determined. They stem from the institutional design that provides for the dual character of the executive. On the one hand, by providing for presidential participation in the appointment of cabinet, a semi-presidential constitution establishes the president as a cabinet's principal whose legitimacy is enhanced by constitutional provisions that provide for popular election of the president and that grant the president some powers in the executive realm. On the other hand, it expects him/her to abstain from trying to influence the prime minister's behavior when the latter is in office.

The political composition of parliament has been the major factor influencing the dynamics of intra-executive relations in premier-presidential regimes. The political party system has been more institutionalized in premier-presidential than in president-parliamentary regimes and, as such, has had a larger effect on the functioning of the executive. Table 2 classifies the cabinets formed in premier-presidential regimes according to the character of majority composition in the parliament and partisan affiliation of the presidents that these cabinets had to coexist with. As the table indicates, both in absolute terms and relative to the total number of cases included in the upper left cell, the coexistence of presidents and prime ministers that belonged to the same one-party or coalition majority in parliament has been predominantly peaceful. The same political orientation diminished room for potential conflict by reducing the differences in opinion about cabinet policies and the appropriate people to conduct those policies.

This was the case, for example, in Lithuania where President Brazauskas had a largely harmonious relationship with three consecutive cabinets led by Lubys, Slezevicius and Stankevicius. Prime ministers and the president belonged to the post-communist Lithuanian Democratic Labor party (LDLP) that held the majority of seats in the 1992-6 Lithuanian parliament. The LDLP was a stable and disciplined party with strong incentives for party members not to factionalize the party and not to defect from its ranks. President Brazauskas was the undisputed leader of the LDLP at the time of the 1992 parliamentary and the 1993 presidential elections in Lithuania (Gelazis, 2001; Urbanavicius, 1999).

Two reported cases of a high level of intra-executive conflict that fall in the upper left cell of Table 2 indicate, however, that the nature and character of the 
Table 2: Distribution of Cabinets in Premier-Presidential Regimes, 1991-2002

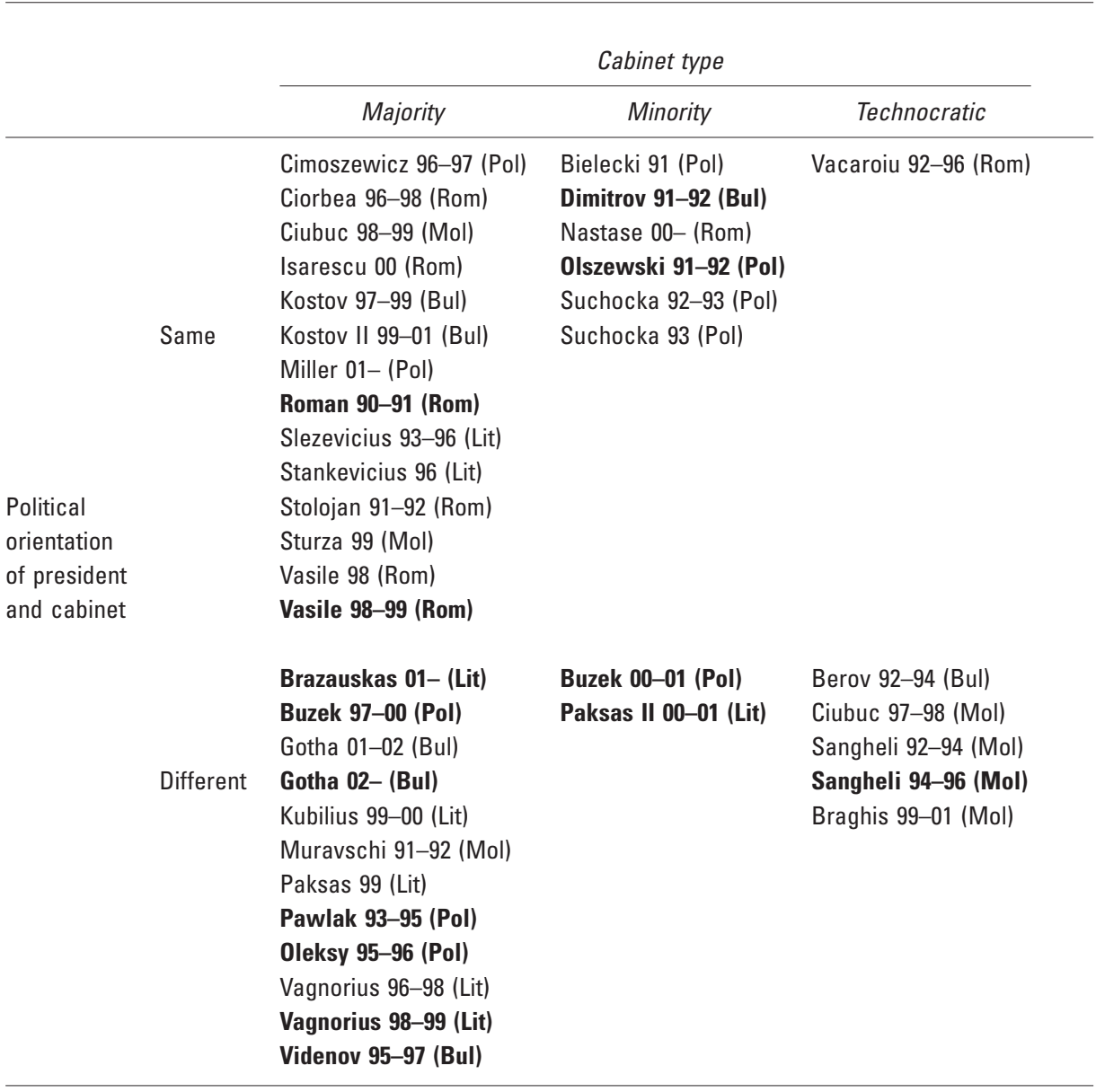

Note: Cases of a high level of intra-executive conflict are highlighted in bold.

parliamentary majority needs to be scrutinized further. Both cases come from Romania but took place in different political contexts and involved different presidents and prime ministers. During the early stage of democratic transition in Romania the coexistence of President Iliescu and Prime Minister Roman was described by observers as highly conflictual. The National Salvation Front (NSF), a political movement to which both leaders belonged and which controlled more than two-thirds of seats in the two chambers of the 1990-2 parliament, was neither disciplined nor ideologically coherent. The president and prime minister presided over two main rival factions inside the NSF (Verheijen, 1999).

The second incident of a high level of intra-executive conflict in Romania took place during the coexistence of President Constantinescu and Prime Min- 
ister Vasile, who belonged to the same umbrella organization, the Democratic Convention (DC), that formed the core of the majority coalition in the 1996-2000 parliament. The DC was a rather loosely organized coalition of parties with Prime Minister Vasile being a member of the largest coalition partner. After the prime minister was weakened, first by the withdrawal of a coalition partner and later by the resignation of more than half of the ministers, President Constantinescu risked dismissing the rival prime minister, although the constitution did not provide the president with such authority (Weber, 2001). The fact that the president and prime minister belong to the same majority coalition thus does not serve as a sufficient condition for avoiding intra-executive confrontation. These two cases suggest that the incentives for president and prime ministers to cooperate might be much less compelling when they are members of a highly factionalized party, or of different parties which form a governing coalition, than when they belong to the same organizationally disciplined and ideologically coherent political party.

The bottom left cell in Table 2 includes all cabinets supported by a parliamentary majority that was different from the president's ideological orientation. As is expected, intra-executive relations in these cases were much more often characterized by intense competition between the president and prime minister. Six out of ten cabinets included in this cell experienced a high level of intra-executive conflict. The bottom middle cell in Table 2 includes two minority cabinets supported by parliamentary coalitions politically opposed to the president. In both cases there was a high level of intra-executive confrontation. A comparison with the results from the bottom left cell indicates that minority cabinets are even more prone to experience conflict than majority cabinets, which are ideologically opposed to the president. In both cases reported in this cell minority status weakened the prime ministers' claims on exclusive control of the executive and its policies and strengthened the presidents' willingness to challenge the prime minister.

The Lithuanian case especially suggests that changes in the political strength of the cabinet may affect the strategic calculations of the president. President Adamkus chose to challenge Prime Minister Paksas's leadership only after the latter was weakened by the disintegration of a majority coalition and had to form his second - this time minority - cabinet in 2000. Earlier, under somewhat similar conditions, Adamkus chose to confront the second but not the first cabinet formed by Prime Minister Vagnorius.

The upper middle cell provides data on the minority cabinets that were of the same political orientation as the president. Intra-executive conflict was much more likely when the president faced an ideologically similar minority cabinet rather than an ideologically similar majority cabinet. A similar logic seemed to apply to presidential behavior whether the president faced a minority cabinet, either ideologically similar or opposed. The minority status of cabinet signaled 
political weakness and was more likely to invite presidential intervention and lead to political confrontation.

Minority cabinets, as well as technocratic cabinets, are largely the products of fragmented parliaments. Romania and Moldova are two countries where parliamentary fragmentation remained high during most of the decade. As conveyed by the effective number of parties (ENP) score of less than or around 3.0, parliamentary fragmentation was low for most of the decade in Bulgaria and Lithuania. Due to electoral changes and political learning, parliamentary fragmentation also dramatically decreased in Poland, where the ENP score for 1991-3 was a staggering 9.80 (Morlino, 2001). Parliamentary fragmentation invites presidential claims on executive leadership by lowering the president's political costs of attacking a prime minister and cabinet that lack solid support in parliament. Conflict occurred every time a prime minister was not willing to accept a higher degree of presidential involvement in executive matters.

Prime ministers did not always choose to defend their powers. Some acquiesced to presidential ambitions to participate more actively in executive decision-making. Technocratic cabinets, which lacked strong and consistent political backing in parliament, were especially prone to grant presidents a larger say in executive matters. Prime Minister Vacaroiu's cooperation with President Iliescu during the office term of the fragmented 1992-6 Romanian parliament and Prime Minister Sangheli's acceptance of President Snegur's leadership during the 1990-4 parliament's office term in Moldova, illustrate this type of intraexecutive coexistence (Crowther, 1997; Verheijen, 1999).

It is indicative that none of the cabinets formed in Romania belong to any cell in the bottom part of Table 2, which lists cabinets that had different political orientation from the president. Romania was the only country among the Eastern European semi-presidential regimes where all majority, minority and technocratic cabinets shared the same political orientation as the president. This can be primarily attributed to the effects of a concurrent electoral cycle (Shugart, 1995). Simultaneous holding of the presidential and parliamentary elections in Romania, which is unique among Eastern European semipresidential regimes, had a tendency both to boost the electoral chances of the presidential party/coalition and to strengthen the ability of this political force to form the cabinet.

In general, parliamentary fragmentation contributes to the perpetuation of ambiguity about where ultimate executive authority resides. The political weaknesses of cabinets, which have often been manifested in the technocratic character of cabinet composition, only highlight the political legitimacy of popularly elected presidents. While premier-presidential constitutional frameworks clearly privilege the prime minister, it is the political context in which the institu- 
tional actors operate that often legitimizes presidential attempts to have a larger say in executive matters.

\section{Probability Logic of Intra-Executive Conflict (Towards a Likelihood Model of Intra-Executive Conflict)}

To summarize some of the arguments introduced in the previous sections of the article and to assess the importance of factors influencing the dynamics of intra-executive relations I specified a binary logit model. Observations on all 67 cases of intra-executive coexistence discussed in this article were used to estimate the model. The number of observations on the cases of intraexecutive coexistence is too small to have a high level of confidence in the model's findings. Since one should consider the results with caution, I choose to present the model's specification only at the end of the article. Nonetheless, since studies have used a maximum likelihood estimation technique for models with an even smaller number of observations ${ }^{14}$ this exercise has the value of subjecting qualitative arguments to a more systematic analysis and suggesting future avenues for research.

The dependent variable in my analysis is conflict level. It takes on a value of 0 when the level of intra-executive conflict was low and a value of 1 when it was high. For each case of intra-executive coexistence I constructed a set of political variables. Regime type variable was given a score of 0 if a cabinet was formed under a premier-presidential regime and a score of 1 if a cabinet was formed under a president-parliamentary constitutional framework. Three dummy variables, majority cabinet, minority cabinet and technocratic cabinet were specified to capture the differences in cabinet type. I included the first two variables in the equation and used technocratic cabinet as a reference category.

Partisanship was another dummy variable introduced into the equation to account for the political orientation of the president and cabinet. If both belonged to the same political party or party coalition the variable was given a score of 1 , and a score of 0 otherwise. The partisanship score for technocratic cabinets was assigned according to the country experts' prevailing perception of cabinet loyalty at the time of cabinet formation. ${ }^{15}$ If the cabinet was perceived at the time of formation as closer to the ideal point of the president rather than parliament it was assigned a score of 1 , and a score of 0 otherwise.

To control for the effects of regime duration on the probability of conflict the transition variable is also included in the analysis. The reasoning behind the inclusion of this variable is that intra-executive relations can be more conflict prone during the earlier years of transition to a semi-presidential political system when political practices of mutual accommodation have not yet been established. The transition variable was assigned a value of 1 if intra-executive 
coexistence took place during the first term of the first popularly elected president and a value of 0 otherwise.

Another control variable, late term presidency was introduced in order to capture the potential effects of the end of a presidential term. Intra-executive conflict may increase as presidential elections approach due to the presidents' attempts to control successions in which prime ministers are usually key players. The late term presidency variable was given a score of 1 if a cabinet coexisted with the president during the last year of a presidential term, and a score of 0 otherwise. The results of the logit regression are summarized in Table 3a.

As Table 3a indicates, partisanship and minority cabinet were found to be significant predictors of intra-executive conflict. The negative sign of a logistic coefficient for partisanship means that belonging to the same political camp decreases the probability of intra-executive conflict. The positive sign of a minority cabinet coefficient indicates that minority cabinets are significantly associated with a higher level of conflict. The fact that the regime type variable was not significant in the specified model suggests that there is no immediate relationship between the type of semi-presidential system and the level of intra-executive confrontation. As the previous sections of the article indicated, although the two alternative semi-presidential constitutional frameworks have different effects

\section{Table 3a: Logistic Coefficients for Regression of Intra-Executive Conflict on Selected Independent Variables}

\begin{tabular}{lc} 
Model & \\
\hline Partisanship & $-1.69^{* *}$ \\
& $(0.623)$ \\
Majority cabinet & 0.99 \\
& $(0.924)$ \\
Minority cabinet & $2.473^{* *}$ \\
& $(1.223)$ \\
Regime type & 0.945 \\
& $(0.921)$ \\
Transition & 0.068 \\
& $(0.616)$ \\
Late term presidency & 0.134 \\
& $(0.666)$ \\
$\mathrm{N}$ & 67
\end{tabular}

Notes: Standard errors are given in parentheses below the logistic coefficients.

${ }^{* *} p<0.05$. 
Table 3b: Probabilities of Intra-Executive Conflict

\begin{tabular}{lcc}
\hline \multicolumn{3}{c}{ Minority cabinet } \\
\hline Partisanship & 0 & 1 \\
0 & & \\
1 & 0.419 & 0.865 \\
& 0.117 & 0.612 \\
\hline
\end{tabular}

on the nature of intra-executive relations, neither of these constitutional frameworks provides immunity from intra-executive confrontation. As results for the late term presidency variable indicate, the regression analysis detected no effects of the end of a presidential term on the probability of intra-executive conflict either. The finding that the transition variable, which can be conceptualized as a learning variable, was not significant also suggests that conflict does not automatically decrease as political actors learn to accommodate each other.

Table $3 \mathrm{~b}$ quantifies key findings of the model. It includes two variables that were found to be significant for predicting intra-executive conflict and provides the predicted probabilities of conflict for the different values of these variables, assuming that other variables in the specified regression model are kept at their means. It shows that a change from a non-minority to minority cabinet leads to an increase in the predicted probability of conflict from 0.117 to 0.612 for cabinets that share the same political orientation as the president, and from 0.419 to 0.865 for cabinets whose political orientation differs from that of the president. A significant increase in the probability of conflict when a president faces a minority cabinet is consistent with the expectation that a president is willing to confront cabinets that are politically vulnerable.

\section{Conclusion}

Intra-executive conflict is a recurrent phenomenon in semi-presidential regimes. Conceptualizing the relationships between the president, the parliament and the cabinet in terms of the multiple principal-agent model helps us to understand the institutional constraints on the cabinet's ability to act independently from the president and the legislature. It is also a starting point for developing an understanding of why the alternative type of alliances - one between the president and prime minister and the other between the prime minister and the legislature - recur in semi-presidential regimes across the postcommunist region. In the president-prime minister-parliament institutional triangle, the prime minister finds him/herself in a subordinate and often precarious position. 
The qualitative analysis undertaken in this article revealed that intra-executive conflict is a frequent phenomenon both in president-parliamentary and premier-presidential regimes. Contrary to one of the initial hypotheses, a preliminary statistical test detected no significant relationship between the type of semi-presidential system and the likelihood of intra-executive conflict. A larger set of observations on intra-executive coexistence and a more nuanced specification of variation in constitutional powers, first of all, with regards to presidential ability to influence parliament's survival in office, are needed to evaluate the robustness of this finding.

The level of party system development was demonstrated to have a profound effect on the dynamics of intra-executive relations. Party-based cabinets dominate the political scene in semi-presidential regimes that have more consolidated and programmatically structured party systems. Strong party links reinforce cabinets' institutional incentives to co-operate with the parliament. At the same time, cabinets without party affiliation or so-called technocratic cabinets were a persistent political phenomenon in semi-presidential regimes with weakly institutionalized party systems.

The prime ministers' stand vis-à-vis presidents was conditioned by their ideological orientation and by the level and character of political support prime ministers could command in parliament. The same political orientation of president and prime minister tended to reduce the likelihood of intra-executive conflict, while a different ideological orientation had the opposite effect on intra-executive relations. When challenged by presidents, prime ministers who led party-based cabinets were more likely than technocratic prime ministers to defend their leadership over the executive. Although the dominant strategy of technocratic cabinets both in president-parliamentary and premier-presidential regimes was to acquiesce to presidential demands for higher control over the executive, a number of instances of intra-executive conflict were registered during the coexistence of presidents with technocratic cabinets led by politically ambitious premiers in president-parliamentary regimes.

Minority cabinets were found to be statistically more likely to experience a high level of intra-executive competition. This might indicate that the functioning of minority cabinets in parliamentary and semi-presidential regimes has different implications for the stability of the political system. While in parliamentary systems minority governments usually rest on the legislators' median policy position and constitute a stable equilibrium point for the political system, minority cabinets in semi-presidential regimes might find themselves in a more precarious situation. The article provides some evidence that in semipresidential regimes presidents who enjoy popular legitimacy and substantial constitutional powers tend to interpret the minority cabinet status as an opportunity to raise their own political profile and the level of their control over the executive. 
A substantial variation in the patterns of intra-executive relationship among semi-presidential regimes has persisted over the first post-communist decade. It reflects the different trajectories of political development that regimes with a similar constitutional framework can pursue. Structuring post-communist countries' experiences with semi-presidentialism along theoretical lines depends on further progress in studying how the effects of constitutional design are mediated by the evolution of party systems across the region.

Appendix: The Level of Intra-Executive Conflict in Semi-Presidential Regimes, 1991-2002

\begin{tabular}{|c|c|c|c|c|c|}
\hline Country & Cabinet & $\begin{array}{l}\text { Level of } \\
\text { conflict }\end{array}$ & Country & Cabinet & $\begin{array}{l}\text { Level of } \\
\text { conflict }\end{array}$ \\
\hline \multirow[t]{8}{*}{ Bulgaria } & Dimitrov 91-92 & High & Lithuania & Slezevicius 93-96 & Low \\
\hline & Berov 92-94 & Low & & Stankevicius 96 & Low \\
\hline & Videnov 95-97 & High & & Vagnorius $96-98$ & Low \\
\hline & Kostov 97-99 & Low & & Vagnorius 98-99 & High \\
\hline & Kostov 99-01 & Low & & Paksas 99 & Low \\
\hline & Gotha 01-02 & Low & & Kubilius 99-00 & Low \\
\hline & Gotha/np 02-* & High & & Paksas II 00-01 & High \\
\hline & & & & Brazauskas 01- & High \\
\hline \multirow[t]{9}{*}{ Moldova } & Muravschi 91-92 & Low & Poland & Bielecki 91 & Low \\
\hline & Sangheli 92-94 & Low & & Olszewski 91-92 & High \\
\hline & Sangheli 94-96 & High & & Suchocka 92-93 & Low \\
\hline & Ciubuc 97-98 & Low & & Pawlak 93-95 & High \\
\hline & Ciubuc 98-99 & Low & & Oleksy 95-96 & High \\
\hline & Sturza 99 & Low & & Cimoszewicz 96-97 & Low \\
\hline & Braghis 99-01 & Low & & Buzek 97-00 & High \\
\hline & Tarlev 01- & Low & & Buzek 00-01 & High \\
\hline & & & & Miller 01- & Low \\
\hline \multirow[t]{7}{*}{ Romania } & Roman 90-91 & High & Russia & Chernomyrdin 92-94 & Low \\
\hline & Stolojan 91-92 & Low & & Chernomyrdin 94-98 & Low \\
\hline & Vacaroiu 92-96 & Low & & Kirienko 98 & Low \\
\hline & Ciorbea 96-98 & Low & & Primakov 98-99 & High \\
\hline & Vasile $98-00$ & High & & Stepashin 99 & Low \\
\hline & Sarescu 00 & Low & & Putin 99 & Low \\
\hline & Nastase 00 & Low & & Kasianov 00- & Low \\
\hline \multirow[t]{7}{*}{ Ukraine } & Fokin 91-92 & Low & Armenia & Arutyunyan 91-92 & Low \\
\hline & Kuchma 92-93 & High & & Arutyunyan 92-93 & High \\
\hline & Masol 94-95 & Low & & Bagratyan 93-95 & Low \\
\hline & Marchuk 95-96 & High & & Bagratyan II 95-96 & Low \\
\hline & Lazarenko 96 & Low & & Bagratyan/np 96 & Low \\
\hline & Lazarenko 96-97 & High & & Sargsyan 96-97 & Low \\
\hline & Pustovoitenko 97-99 & Low & & Kocharyan 97-98 & High \\
\hline
\end{tabular}


Appendix: Continued

\begin{tabular}{cccccc}
\hline Country & Level of & & & \\
Conflict & Country & Cabinet & $\begin{array}{r}\text { Level of } \\
\text { conflict }\end{array}$ \\
\hline & Yushchenko 99-01 & Low & Darbinyan 98-99 & Low \\
& Kinakh 01-02 & Low & Sargsyan 99 & Low \\
& Yanykovych 02- & Low & Sargsyan 99-00 & High \\
& & & Margaryan 00- & Low \\
\hline
\end{tabular}

Note: ${ }^{*} n p^{\prime}$ means 'new president'; this abbreviation refers to coexistence of an incumbent prime minister with a newly elected president.

(Accepted: 11 May 2005)

\author{
About the Author \\ Oleh Protsyk, European Centre for Minority Issues, Schiffbrücke 12, D 24939 Flensburg, Germany; \\ email:protsyk@ecmi.de
}

\title{
Notes
}

I would like to thank three anonymous Political Studies referees for their very helpful comments.

1 Duverger proposed three criteria for defining semi-presidentialism: (1) the president of the republic is elected by universal suffrage; (2) s/he possesses quite considerable powers; (3) there is also a prime minister and ministers who possess executive and governmental powers and can stay in office only if the parliament does not show its opposition to them (Duverger 1980). The second criterion has attracted the most criticism to date.

2 Russia, after 1993, is often described in the literature as a 'super-presidential' political regime (Fish, 2000). A huge bureaucratic apparatus of presidential office, rule by presidential decrees, formal and informal presidential control over other branches of government and public expenditures are all described in the literature as indicators of super-presidentialism. Fish and other authors essentially rely on sociological categories to describe the political regime in Russia. In classifying Russia as a semi-presidential regime, I rely on the formal constitutional criteria proposed by Duverger. For the purposes of my analysis of the effects of variation in constitutional framework, the Russian constitutional arrangement meets the Duverger criteria and thus falls into the category of semi-presidential regimes.

3 The immaturity of democratic institutions in the Caucasian and Central Asian republics of the former Soviet Union, which is perpetuated by authoritarian practices of conflict management in general, and by violent handling of political competition in particular, disqualified several nominally semi-presidential regimes from being included in the analysis. Armenia, similarly to Russia and Ukraine, was consistently rated by Freedom House Country Index as 'Partly Free'. All other Caucasian and Central Asian semi-presidential republics either oscillated between 'Partly Free' and 'Not Free' status or were rated 'Not Free' throughout the decade. See 'Freedom in the World' at http://www.freedomhouse.org/research/index.htm

4 As stated in the introductory paragraph, the article attempts to analyze the experience of post-communist semipresidential regimes in East Central Europe and the Former Soviet Union. Semi-presidential regimes found in the Balkan region were not included in the analysis.

5 For a theoretical discussion of the utility of principal-agent models in the political setting see Bergman et al. (2000); Huber and Lupia (2001); Moe (1994).

6 Formal symmetry of cabinet dismissal powers, however, can be offset if other constitutional provisions exist which limit the parliament's power of cabinet dismissal, which is the case in a number of constitutions tailored by the presidents of post-Soviet republics (Frye, 1997). The existence of such constitutional norms makes it more likely that a political system will be characterized by an alliance of the president and prime minister vis$\grave{a}$-vis the legislature and concomitant conflict between a united executive and the legislature.

7 Shugart and Carey (1992), for example, attribute the peacefulness of cohabitation to the unique characteristics of the French political system and stress the dangers that cohabitation may present in less consolidated politi- 
cal systems. Elgie (1999b) also seems to argue that three recent cases of cohabitation in France (1986-8, 1993-5 and 1997-) were periods of rather peaceful coexistence largely due to a relatively clear division of responsibility between the president and the prime minister (Elgie, 1999b).

8 A cabinet is defined as technocratic when a prime minister and majority of cabinet members do not have formal party affiliation. Policy expertise and government experience rather than party ties are usually cited as the criteria employed to select candidates for ministerial positions in technocratic cabinets. A cabinet is defined as a party-based cabinet if it acts on the mandate of a party or party coalition and a prime minister and at least 50 per cent of cabinet members are formally affiliated with that political force at the moment of cabinet formation.

9 Armenia and Moldova are the only countries that were not systematically covered by the EECR during the analyzed period (Armenia did not have any coverage at all; the coverage for Moldova started only in 1997). I relied on Radio Free Europe/Radio Liberty (RFE/RL) reports to form a judgment on intra-executive relations in Moldova for the early years of the post-communist transition. For Armenia, I relied on the same sources for the entire period. See Radio Free Europe /Radio Liberty (RFE/RL) Daily Reports, 1991-9; RFE/RL News line, 1999-2002; RFE/RL Caucasus Reports, 1998-2002.

10 Adopting a more nuanced classification, which would allow differentiation between various intensities of intraexecutive confrontation, was not feasible due to the limitations of the available coverage of intra-executive relations. Although EECR provides the most systematic analytical update on domestic politics in individual countries across the region and EECR reporters follow the same guidelines and are socialized to similar norms, their reports were not tailored specifically to provide an exhaustive coverage of intra-executive relations.

11 There were a number of other changes to the rules regulating the relationships between the president, parliament and cabinet in Ukraine during the 1990s (Wolczuk, 2001). These rules were modified in 1992 (emergency powers for the prime minister), 1993 (expiration of those powers), 1995 (Constitutional Agreement) and 1996 (Constitution). Under each of these arrangements, however, the president continued to control the power of cabinet dismissal.

12 The formation of the Kirienko cabinet in spring 1998 demonstrates the powerful effects that the presidential constitutional option to dissolve parliament in the process of cabinet formation has on parliamentary deputies' behavior. See Russia Update, East European Constitutional Review (EECR), V.7 (3), 1998.

13 See Morgan-Jones and Schleiter (2004) for a more critical view of the Russian president's ability to dominate the cabinet formation process.

14 See, for example, Spector and Mazzeo (1980).

15 For a recent analysis of cabinet formation outcomes in the semi-presidential regimes included in this study, see Protsyk (2005). The cited paper analyzes cabinet formation process and summarizes the country experts' opinions with regard to the prime minister's location on the continuum between the ideal preferences of president and parliament. For a detailed discussion of the Russian case, see Morgan-Jones and Schleiter (2004).

\section{References}

Bahro, H., Bayerlein, B. H. and Vesser, E. (1998) 'Duverger's Concept: Semi-Presidential Government Revisited', European Journal of Political Research, 34 (6), 201-24.

Baylis, T. (1996) 'Presidents versus Prime Ministers: Shaping the Executive Authority in Eastern Europe', World Politics, 48 (3), 297-323.

Bergman, T., Muller, W. C. and Strom, K. (2000) 'Introduction: Parliamentary Democracy and the Chain of Delegation', European Journal of Political Research, 37 (3), 255-60.

Birch, S. (2000) Elections and Democratization in Ukraine. Basingstoke: Macmillan.

Crowther, W. (1997) 'The Politics of Democratization in Post-Communist Moldova', in K. Dawisha and B. Parrott (eds), Democratic Changes and Authoritarian Reactions in Russia, Ukraine, Belarus, Moldova. Cambridge: Cambridge University Press, pp. 282-330.

Duverger, M. (1980) 'A New Political System Model: Semi-Presidential Government', European Journal of Political Research, 8 (2), 165-87.

East European Constitutional Review (EECR) (2001) 'Lithuania Update', 10 (2-3), 31-4.

Elgie, R. (1998) 'The Classification of Democratic Regime Types: Conceptual Ambiguity and Contestable Assumptions', European Journal of Political Research, 33 (2), 219-38.

Elgie, R. (1999a) 'Semi-Presidentialism and Comparative Institutional Engineering', in R. Elgie (ed.), SemiPresidentialism in Europe. Oxford: Oxford University Press, pp. 281-99.

Elgie, R. (1999b) 'France', in R. Elgie (ed.), Semi-Presidentialism in Europe. Oxford: Oxford University Press, pp. $67-86$. 
Fish, S. (2000) 'The Executive Deception: Superpresidentialism and the Degradation of Russian Politics', in V. Sperling (ed.), Building the Russian State. Boulder CO: Westview Press, pp. 177-92.

Frye, T. (1997) 'A Politics of Institutional Change: Post-Communist Presidencies', Comparative Political Studies, 30 (5), 523-52.

Fuller, L. (1999) 'Armenian President Unveils New Cabinet', RFE/RL Caucasus Report 24.

Gelazis, N. (2001) 'Institutional Engineering in Lithuania: Stability through Compromise', in J. Zielonka (ed.), Democratic Consolidation in Eastern Europe: Institutional Engineering. Oxford: Oxford University Press, pp. 165-85.

Golosov, G. (2003) Political Parties in the Regions of Russia: Democracy Unclaimed. London: Lynne Rienner Publishers.

Harasymiw, B. (2002) Post-Communist Ukraine. Toronto: CIUS Press.

Huber, J. D. and Lupia, A. (2001) 'Cabinet Instability and Delegation in Parliamentary Democracies', American Journal of Political Science, 45 (1), 18-32.

Huskey, E. (1999) Presidential Power in Russia. Armonk NY: M.E. Sharpe.

Jasciewicz, K. (1997) 'Poland', in R. Taras (ed.), Post-Communist Presidents. Cambridge: Cambridge University Press, pp. 130-67.

Kitschelt, H. (1995) 'Formation of Party Cleavages in Post-Communist Democracies', Party Politics, 1 (4), 447-72.

Kitschelt, H., Mansfeldova, Z., Markowski, R. and Toka, G. (1999) Post-Communist Party Systems, Competition, Representation and Inter-Party Cooperation. Cambridge: Cambridge University Press.

Lewis, P. G. (ed.) (2001) Party Development and Democratic Change in Post-Communist Europe: The First Decade. London: Frank Cass.

Lowenhardt, J. (ed.) (1998) Party Politics in Post-Communist Russia. London: Cass Publishers.

McFaul, M. (2001) 'Explaining Party Formation and Nonformation in Russia: Actors, Institutions, and Chance', Comparative Political Studies, 34 (10), 1159-87.

Moe, T. M. (1994) 'Integrating Politics and Organizations: Positive Theory and Public Administration', Journal of Public Administration Research \& Theory, 4 (1), 17-25.

Morgan-Jones, E. and Schleiter, P. (2004) 'Governmental Change in a President-Parliamentary Regime: The Case of Russia 1994-2003', Post-Soviet Affairs, 20 (2), 132-63.

Morlino, L. (2001) 'Constitutional Design and Problems of Implementation in Southern and Eastern Europe', in J. Zielonka (ed.), Democratic Consolidation in Eastern Europe: Institutional Engineering. Oxford: Oxford University Press, pp. 48-109.

Moser, R. (2001) Unexpected Outcomes: Electoral Systems, Political Parties, and Representation in Russia. Pittsburgh PA: University of Pittsburgh Press.

Pasquino, G. (1997) 'Semi-Presidentialism: A Political Model at Work', European Journal of Political Research, 31 (1), 128-37.

Protsyk, O. (2003) 'Troubled Semi-Presidentialism: Stability of the Constitutional System and Cabinet in Ukraine', Europe-Asia Studies, 55 (7), 1077-95.

Protsyk, O. (2005) 'Prime Ministers' Identity in Semi-Presidential Regimes: Constitutional Norms and Cabinet Formation Outcomes', European Journal for Political Research, 44 (5), 721-48.

Protsyk, O. and Wilson, A. (2003) 'Centre Politics in Russia and Ukraine: Power, Patronage, and Virtuality', Party Politics, 9 (6), 703-27.

Roper, S. D. (2002) 'Are All Semipresidential Regimes the Same? A Comparison of Premier-Presidential Regimes', Comparative Politics, 34 (3), 253-76.

Shugart, M. S. and Carey, J. M. (1992) Presidents and Assemblies: Constitutional Design and Electoral Dynamics. Cambridge: Cambridge University Press.

Shugart, M. S. (1995) 'The Electoral Cycle and Institutional Sources of Divided Presidential Government', American Political Science Review, 89 (2), 327-43.

Siaroff, A. (2003) 'Comparative Presidencies: The Inadequacy of the Presidential, Semi-Presidential and Parliamentary Distinction’, European Journal of Political Research, 42 (3), 287-312.

Spector, L. and Mazzeo, M. (1980) 'Probit Analysis and Economic Education', Journal of Economic Education, $11(2), 37-44$. 
Taras, R. (ed.) (1997) Post-Communist Presidents. Cambridge: Cambridge University Press.

Urbanavicius, D. (1999) 'Lithuania', in R. Elgie (ed.), Semi-Presidentialism in Europe. Oxford: Oxford University Press, pp. 150-69.

Verheijen, T. (1999) 'Romania', in R. Elgie (ed.), Semi-Presidentialism in Europe. Oxford: Oxford University Press, pp. 193-215.

Weber, R. (2001) 'Constitutionalism as a Vehicle for Democratic Consolidation in Romania', in J. Zielonka (ed.), Democratic Consolidation in Eastern Europe: Institutional Engineering. Oxford: Oxford University Press, pp. 212-42.

White, S. (1999) 'Russia', in R. Elgie (ed.), Semi-Presidentialism in Europe. Oxford: Oxford University Press, pp. 201-23.

Wolczuk, K. (2001) The Moulding of Ukraine: The Constitutional Politics of State Formation. Budapest: Central European University Press. 